\title{
Effects of riparian vegetation on the structure of the marginal aquatic habitat and the associated fish assemblage in a tropical Brazilian reservoir
}

\author{
Gabriel de Barros Moreira Beltrão ${ }^{1}$, \\ Elvio Sergio Figueredo Medeiros ${ }^{2,3}$ \& Robson Tamar da Costa Ramos ${ }^{1}$ \\ ${ }^{1}$ Departamento de Sistemática e Ecologia, Universidade Federal da Paraíba - UFPB \\ CEP 58059-900, João Pessoa, PB, Brazil \\ ${ }^{2}$ Centro de Ciências Biológicas e Sociais Aplicadas, Universidade Estadual da Paraíba - UEPB \\ Campus V, CEP 58020-540, João Pessoa, PB, Brazil \\ ${ }^{3}$ Corresponding author: Elvio Medeiros,e-mail: elviomedeiros@uepb.edu.br
}

BELTRÃO, G. B. M., MEDEIROS, E. S. F. \& RAMOS, R. T. C. Effects of riparian vegetation removal on the structure of the marginal aquatic habitat and the associated fish fauna in a tropical Brazilian reservoir. Biotra Neotrop., 9(4): http://www.biotaneotropica.org.br/v9n4/en/abstract?article+bn00709042009.

\begin{abstract}
Riparian zones represent areas of strong biological, physical and chemical interaction between terrestrial and aquatic ecosystems. These areas are usually typified by high diversity of fauna, flora and environmental processes. The present study evaluates the littoral habitat structure and its fish fauna related to associations between presence and absence of natural riparian vegetal cover, in a reservoir in northeastern Brazil. Sampling was performed on marginal areas where riparian vegetation was present and where it had been removed for the plantation of sugar cane. For each type of marginal area three replicate sites were sampled during the wet season. Data on the habitat structure (submerged elements and substrate composition), fish and water quality were collected. The data was analyzed using Shannon-Wiener's diversity index and Pielou's equitability. Non-metric Multidimensional Scaling and the Multi-Response Permutation Procedure were used to evaluate similarities between sites. The structure of the habitat was more diverse in sites were natural riparian vegetation was still present. Muddy substrate was more abundant in areas with riparian vegetation whereas sandy substrate was more abundant in areas where riparian vegetation had been removed. Measured physico-chemical parameters and nutrients remained nearly constant across all sites. Metynnis lippincottianus and Crenicichla menezesi were more associated with the habitat in areas where riparian vegetation was removed, whereas Cichlasoma orientale and Cichla ocellaris were strongly correlated to forested areas.
\end{abstract}

Keywords: riparian zone, habitat structure, water management, conservation.

BELTRÃO, G. B. M., MEDEIROS, E. S. F. \& RAMOS, R. T. C. Efeitos da cobertura vegetal ripária na estrutura do habitat aquático marginal e na fauna de peixes associada em um reservatório tropical brasileiro. Biotra Neotrop., 9(4): http://www.biotaneotropica.org.br/v9n4/pt/abstract?article+bn00709042009.

Resumo: A zona ripária representa uma área de importantes interações, sejam biológicas, físicas ou químicas, entre o ecossistema terrestre e aquático. Essas áreas são geralmente caracterizadas por uma alta diversidade de fauna, flora e processos ecológicos. Este estudo avalia a estrutura do habitat aquático e a fauna de peixes com relação à presença e ausência da mata ciliar natural em um reservatório no Nordeste brasileiro. Amostragens foram realizadas em áreas marginais onde a mata ciliar estava presente e onde esta havia sido removida para o plantio de cana-de-açúcar. Em cada área, três pontos de coleta foram amostrados durante o período chuvoso. Dados sobre a estrutura do habitat (elementos submersos e composição do substrato), peixes e qualidade da água foram coletados. Os dados foram analisados usando o índice de diversidade de Shannon-Wiener e a equitabilidade de Pielou. Escalonamento multidimensional não métrico associado a um procedimento de permutações multiplas foi usado para avaliar as similaridades entre os pontos de coleta. A estrutura do habitat mostrou-se mais diversa em locais onde a mata ciliar não havia sido removida. Lama foi o tipo de substrato mais abundante em áreas onde a mata ciliar esteve intacta, enquanto que areia foi o tipo de substrato mais comum em áreas onde a mata ciliar foi removida. Variáveis físico-químicas e nutrientes dissolvidos na água apresentaram valores relativamente constantes em todos os locais estudados. Metynnis lippincottianus e Crenicichla menezesi estiveram associados com áreas onde a mata ciliar foi removida, enquanto Cichlasoma orientale e Cichla ocellaris estiveram mais fortemente correlacionados com áreas onde a mata ciliar estava preservada.

Palavras-chave: zona ripária, estrutura do habitat, manejo, conservação. 


\section{Introduction}

Riparian zones represent areas of strong biological, physical and chemical interaction between terrestrial and aquatic ecosystems (Gregory et al. 1991). These areas are usually typified by high diversity of fauna, flora and environmental processes (Pusey \& Arthington 2003). The importance of the riparian zones to the aquatic environment is well recognized, as the terrestrial primary productivity derived from riparian zone is known as an important source of energy to riverine foodwebs (Vannote et al. 1980, Junk et al. 1989). The influence of the riparian zone on aquatic systems also includes thermal buffering, provision of shade, nutrient interception, storage and release and enhancement of bank stability (Bunn et al. 1999, Pusey \& Arthington 2003, Søvik \& Syversen 2008).

One of the most important roles of the riparian zone is the provision of coarse woody material as habitat and substrate for the aquatic fauna, such as invertebrates (Richards et al. 1997) and fish (Boys \& Thoms 2006). The aquatic habitat has been found to be associated with the riparian vegetation or other correlated variables, such as turbidity and shading of the margins (Medeiros et al. 2008). Therefore the state of this living space will influence the biotic structure and organization within aquatic systems (Mugodo et al. 2006).

The physical habitat of many aquatic environments worldwide has been degraded by human activities (Mugodo et al. 2006). Given

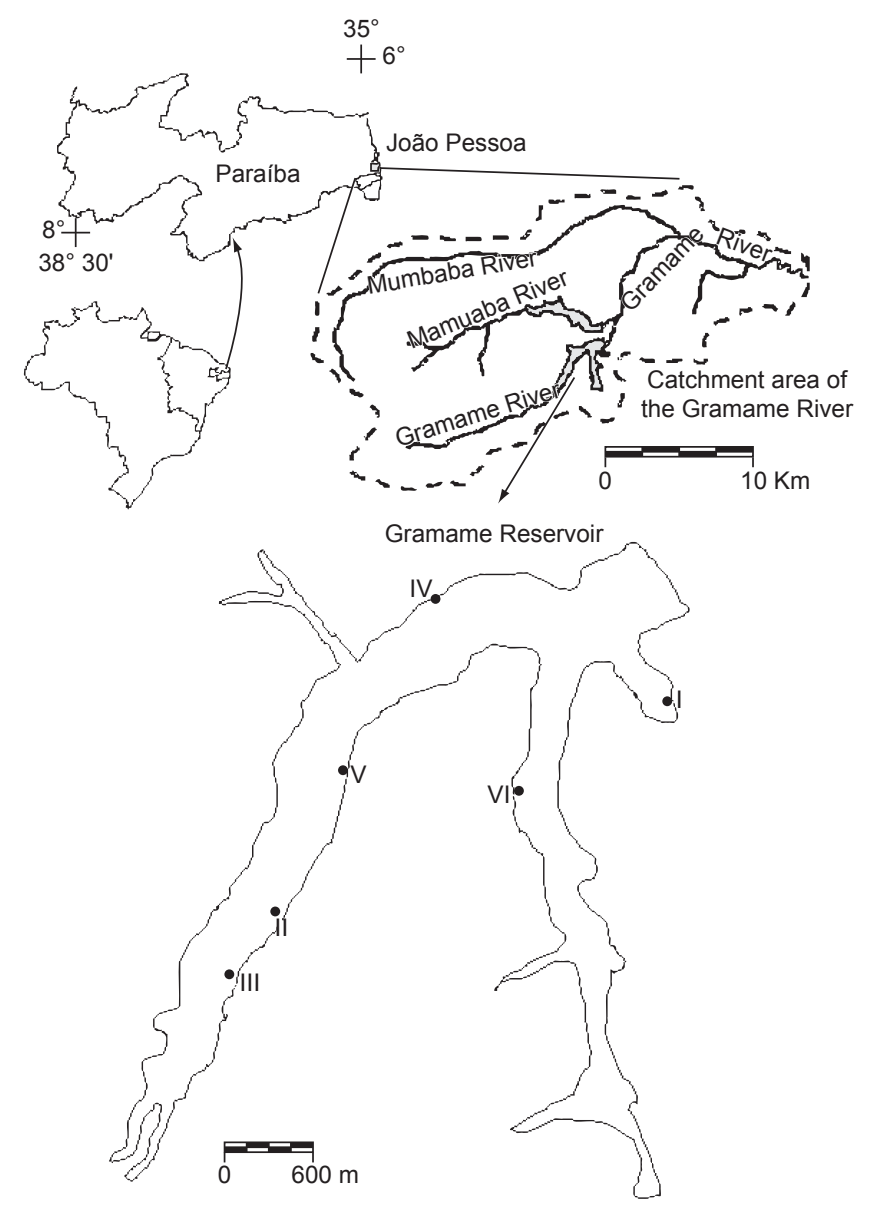

Figure 1. Location of the Gramame reservoir in the catchment area of the Gramame River (Paraíba, Brazil) and the study sites (I, II, III = forested margins and IV, V, VI = non-forested margins).

Figura 1. Localização do reservatório de Gramame na bacia de drenagem do Rio Gramame (Paraíba, Brasil) e dos pontos de coleta (I, II, III = mata ciliar natural presente e IV, V, VI = mata ciliar ausente). the great number of links between riparian vegetation and the aquatic ecosystems, it is not surprising that fish assemblages diversity and the composition and structure of their habitat have been linked to variations in the riparian cover (Vono \& Barbosa 2001). The present study evaluates the associations between presence and absence of the natural riparian vegetal cover versus the littoral habitat structure and fish fauna in the Gramame reservoir, Paraíba, Brazil.

\section{Study area}

This study was conducted at the Gramame reservoir (located $7^{\circ} 17^{\prime} 40.42$ ' S and $34^{\circ} 57^{\prime} 28.25^{\prime}$ ' W, in the state of Paraíba, Brazil) formed in 1988 after the damming of the Gramame River. The Gramame River starts at the municipality of Pedras de Fogo (reference location $7^{\circ} 24^{\prime} 22.50^{\prime \prime} \mathrm{S}$ and $35^{\circ}$ 6' 38.65" W, Paraíba) and runs approximately $54 \mathrm{~km}$ northeast where it meets the sea $15 \mathrm{~km}$ south of João Pessoa, the largest city in the state of Paraíba (Figure 1). Its two major tributaries are the Mumbaba River which joins the Gramame on its lower reach, and the Mamuaba River, which joins the Gramame in the transition between its middle-lower reaches (Figure 1) (Goldfarb et al. 2002). Together with another reservoir built in the Mamuaba River, the complex GramameMamuaba has a capacity for $56.937 .000 \mathrm{~m}^{3}$.

Between January and December 2007, the monthly volume of the reservoir varied from $73.4 \%$ of the total volume (in February) to a surplus of $102.2 \%$ in June, when the reservoir overflowed via the spillway. Overflow continued from July to September (Figure 2). Land use in the Gramame basin corresponds mostly to agriculture $(96.5 \%)$. Natural vegetation and areas inundated by reservoirs represent 1.7 and $1.6 \%$, respectively, and urbanized areas correspond to $0.2 \%$ (Goldfarb et al. 2002). Even though studies on the riparian vegetation of the Gramame reservoir are scarce, Santos et al. (2002) reported for the Gramame River basin the presence of Atlantic Forest $\left(38.20\right.$ km²), "Várzea" vegetation $\left(20.74 \mathrm{~km}^{2}\right)$, Grassland $\left(11.37 \mathrm{~km}^{2}\right)$ and Mangrove $\left(6.13 \mathrm{~km}^{2}\right)$. This vegetation corresponds to $12.9 \%$ of the total area of the Gramame river basin whereas only $20 \%$ of the riparian vegetation is still standing. According to these authors patches of Atlantic Forest surrounded by cultivated areas are the major land cover in the surroundings of the Gramame reservoir, however the presence of Coastal "Tabuleiros" has been reported for the middlelower reaches of Gramame River near the Gramame reservoir (Superintendência de Administração do Meio Ambiente 2004).

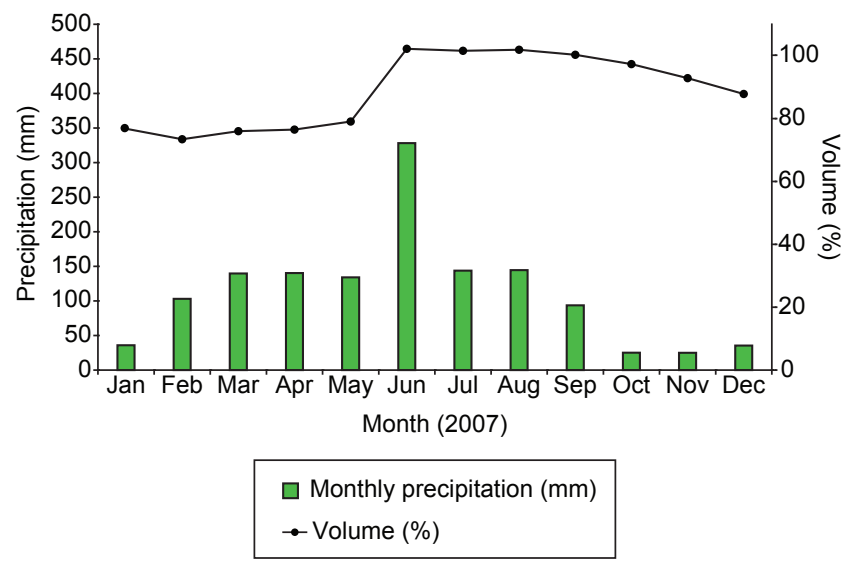

Figure 2. Monthly precipitation $(\mathrm{mm})$ in the study area and percent total volume of the Gramame-Mamuaba reservoirs (Paraíba, Brazil) during 2007 (sources: http://www.cptec.inpe.br and http://www.aesa.pb.gov.br).

Figura 2. Precipitação mensal (mm) na área de estudo e volume total percentual dos reservatórios Gramame-Mamuaba (Paraíba, Brasil) em 2007 (fontes: http://www.cptec.inpe.br e http://www.aesa.pb.gov.br). 
The Gramame River basin is affected by several issues related to water quality, such as domestic and industrial waste, pesticides, solid residuals, irrigation and mining activities (Santos et al. 2002). Water in the river basin for human consumption is managed by Companhia de Água e Esgotos do Estado da Paraíba (CAGEPA) and several organizations from the private sector are licensed to extract water for irrigation and industrial/commercial use (Silva et al. 2002b). According to Silva et al. (2002a) the surface hydrologic potential for the Gramame River basin is $10.21 \mathrm{~m}^{3} / \mathrm{s}$. Of this, $2571 \mathrm{~L} / \mathrm{s}$ are extracted for water consumption, $425 \mathrm{~L} / \mathrm{s}$ being from the Mumbaba River. These demands have grown since 2002 and a management committee for the Gramame River basin is currently being proposed.

\section{Material and Methods}

Sampling of different habitat variables, water quality parameters and the fish fauna was performed during the wet season, between June and September 2007, when the water level was at its maximum in the Gramame reservoir, therefore maximizing contact between riparian vegetation and the aquatic marginal habitat. During this period collections were performed on two different types of marginal areas of the reservoir:

1)Forested areas, where riparian vegetation had not been removed; and

2) Non-forested areas, where the natural riparian vegetation was removed for the plantation of sugar cane.

For each type of marginal area three replicate sites were sampled once during the wet season. Sites I, II and III represent areas where riparian vegetation was not removed and sites IV, V and VI represent areas where riparian vegetation was removed (Figure 1). The natural riparian vegetation or marginal vegetation in the study sites corresponds to secondary Atlantic Forest.

The structure of the marginal aquatic habitat was quantified following methodology used by Medeiros et al. (2008). It was divided into two components:

i) The habitat elements, which correspond to marginal underwater and littoral structures (such as aquatic macrophytes, submerged vegetation, vegetal cover, debris, leaf litter, algae, root masses, etc); and

ii)The substrate composition (mud, sand, gravel, cobbles, rocks and bedrock).

These elements of habitat structure were visually estimated (given the high water transparency) as their proportional cover in survey points of one square meter (determined using a square frame). Twelve survey points were evaluated within each sampling site, and both habitat elements and substrate composition were expressed as their average proportional contribution to site margins. Water depth was determined with a measuring pole at approximately equivalent distances along a transect to represent habitat depth (average depth of the first $3 \mathrm{~m}$ from the terrestrial-aquatic interface) and maximum depth.

Three sub-samples of water for analysis of total phosphorus $\left(\mu \mathrm{g} . \mathrm{L}^{-1}\right)$, ammonium $\left(\mu \mathrm{g} . \mathrm{L}^{-1}\right)$ and nitrite $\left(\mu \mathrm{g} . \mathrm{L}^{-1}\right)$, and one water sample for analysis of chlorophyll- $\alpha\left(\mu \mathrm{g} . \mathrm{L}^{-1}\right)$ were collected from each site, placed on ice and taken to the Laboratório de Ecologia Aquática of Universidade Federal da Paraíba (UFPB). Analyses were performed using the Standard Methods for the Examination of Water and Wastewater (APHA 1998) for all nutrients except for chlorophyll- $\alpha$ which was analyzed based on Lorenzen (1967). Nutrients are expressed as the average ( \pm standard deviation, SD) of the three measurements. The physico-chemical variables were measured on three different locations (sub-samples) at each study site and are expressed as the average $( \pm \mathrm{SD})$ of the three measurements. Water temperature $\left({ }^{\circ} \mathrm{C}\right)$ and dissolved oxygen $\left(\mathrm{mg} . \mathrm{L}^{-1}\right)$ were measured with an oxygen meter (Lutron DO-5510), and transparency $(\mathrm{cm})$ was measured with a Secchi disk. Conductivity $(\mu \mathrm{S} / \mathrm{cm})$ and $\mathrm{pH}$ were measured with portable equipments (respectively, TECNOPON MCA-150 and TECNOPON MPA-210).

Sampling of fish was diurnal and performed along a stretch of $100 \mathrm{~m}$ on the margins of each study site. Sampling was concentrated along the margins where interactions between riparian vegetation and the aquatic habitat have been reported to be stronger (Pusey \& Arthington 2003, Medeiros et al. 2008). Given the low density of fish during the wet season in the reservoir, the effort of capture included a wide range of fishing techniques and sampling was performed for a full day 05:00 to 20:30 hours at each of the six replicate sites (Table 1). The range of fishing techniques used and the effort of capture were the same for all six study sites. Mesh size for gill nets were 50, 45, 40 and $20 \mathrm{~mm}$ (each net was $10 \mathrm{~m}$ long and $1.5 \mathrm{~m}$ high). Two seine nets were used: a $4 \mathrm{~m}$ net with $5 \mathrm{~mm}$ mesh $(1.5 \mathrm{~m}$ high) and a $20 \mathrm{~m}$ net with mesh of $10 \mathrm{~mm}(2 \mathrm{~m}$ high). Fishing was also performed using two bamboo rods (2.90 and $1.95 \mathrm{~m})$ with sizes 10 and 12 barbless hooks (the hooks used were of the single type, light to heavy gauge, ringed eye, standard shank, round bend, Aberdeen shape and offset point reversed, according to the classification of Bailey et al. 2001). The bait used was the common garden worm (Order Haplotaxida). A fiber reel rod $(1.60 \mathrm{~m})$, medium action and line weight of $10 \mathrm{lb}$, was also used with two plug shallow-diver lures (Bailey et al. 2001), 7.0 and $10.0 \mathrm{~cm}$, respectively. Fish caught were fixed in $10 \%$ formalin in the field and later transferred to $70 \%$ ethanol and identified in the Laboratório de Ictiologia of Departamento de Sistemática e Ecologia (UFPB).

Habitat diversity was summarized using the Shannon-Wiener's (H') diversity index and Pielou's equitability (Magurran 1996). Non-metric Multidimensional Scaling (NMS) of the standardized arcsine-squareroot-transformed data (Bray-Curtis similarity) (McCune \& Grace 2002) was used to evaluate variations in habitat composition between sites and areas (forested and non-forested). The Multi-Response Permutation Procedure (MRPP) (Biondini et al. 1985, McCune \& Grace 2002) was used to test significance of differences in habitat composition between sites and areas. MRPP is a non-parametric procedure for testing the hypothesis of no difference between two or more groups of entities defined a priori. For all MRPP analyses, the chance-corrected within-group agreement (A) is presented as a measure of the degree of within group homogeneity,

Table 1. Fishing techniques used in the present study and the capture effort for each technique per sampling occasion. See text for description of each technique.

Tabela 1. Técnicas de coleta de peixes utilizadas e esforço de captura para cada técnica. Ver texto para descrição mais detalhada.

\begin{tabular}{llc}
\hline \multicolumn{1}{c}{ Technique } & Time of continuous sampling & Total effort \\
\hline Passive methods & & \\
\hline Gill nets & 05:00-09:30 AM; & 9 hours \\
& 04:00-08:30 PM & \\
Bamboo rods & 06:00-09:00 AM; & 8.5 hours \\
& 01:30-03:30 PM; & \\
& 04:30-08:00 PM & \\
& 06:00-09:00 AM; & 8.5 hours \\
Reel rods & 01:30-03:30 PM; & \\
& $04: 30-08: 00$ PM & \\
& & 3 tows \\
Active methods & $10: 30$ AM-12:30 PM & 20 tows \\
\hline 20 m seine net & $10: 30$ AM-12:30 PM & \\
4 m seine net &
\end{tabular}


compared to random expectation. The association between habitat and the fish fauna was evaluated using a biplot of the NMS habitat plot and the fish fauna composition. In the ordination plot, axes have been re-scaled from the lowest score on the axis to the highest score, therefore axes range from 0 to 100 . With this method, the points occupy the whole space on every axis, regardless of the range in scores (McCune \& Grace 2002). All statistics were performed on PC-ORD 4.27 (McCune \& Mefford 1999).

\section{Results}

Habitat structure was more diverse in sites were natural riparian vegetation was present. Richness of habitats varied between 14 and 15 elements $\left(H^{\prime}=2.0\right)$ in sites were the natural vegetal cover was absent and between 17 and 19 elements $\left(H^{\prime}=2.2\right)$ in sites with reminiscent riparian vegetation. Aquatic macrophyte proportional cover was similar between the two groups of sites, however Nymphoides indica $(14.7 \pm 19.9 \%)$ was more abundant in areas without riparian vegetation, whereas Salvinia auriculata (12.4 $\pm 7.7 \%)$ and Tonina sp. $(1.5 \pm 1.3 \%)$ were more abundant in areas with riparian vegetation
(Table 2). Eleocharis sp. was relatively abundant across all sites. In general the other habitat elements were more abundant in forested margins: vegetal cover $(75.9 \pm 7.7 \%)$, leaf litter $(52.0 \pm 27.5 \%)$ and debris, both large $(9.7 \pm 2.3 \%)$ and small $(1.7 \pm 1.9 \%)$. Only grass $(41.4 \pm 27.1 \%)$ and submerged vegetation $(6.4 \pm 6.0 \%)$ were more abundant in areas were riparian cover had been removed. Forested areas were also deeper, with greater average littoral depths $(38.3 \pm 4.8 \mathrm{~cm})$ (Table 2). Substrate composition was also different between forested and non-forested littoral areas, with mud being more abundant in areas with riparian vegetation $(59.9 \pm 21.9 \%)$ and sand being more abundant in areas where riparian vegetation had been removed $(87.0 \pm 7.2 \%)$ (Table 2$)$.

Patterns described above are corroborated by the ordination plot (Figure 3), which shows clear segregation between sites in forested and non-forested areas. The NMS two-dimensional solution explained $90.3 \%$ of the variation in the original space, resulting in a mean stress of 3.7. Of the explained variation $56.5 \%$ is attributed to the first axis. Sites IV, V and VI (where riparian vegetation was removed) are positively correlated with both axes, therefore spread

Table 2. Percentage cover ( \pm standard deviation) of habitat elements for both marginal habitat and substrate composition occupying the margins of the study sites in the Gramame reservoir, Paraíba, Brazil.

Tabela 2. Percentual de cobertura ( \pm desvio padrão) dos elementos do habitat para o habitat marginal e para a composição do substrato nas margens dos pontos de coleta (reservatório de Gramame, Paraíba, Brasil).

\begin{tabular}{|c|c|c|c|c|c|c|}
\hline \multirow{2}{*}{$\begin{array}{c}\text { Area } \\
\text { Sampling site }\end{array}$} & \multicolumn{3}{|c|}{ Forested margins } & \multicolumn{3}{|c|}{ Non-forested margins } \\
\hline & I & II & III & IV & $\mathbf{V}$ & VI \\
\hline \multicolumn{7}{|l|}{ Aquatic Macrophytes } \\
\hline Echhornia crassipes & 0.0 & 0.0 & 0.0 & 0.0 & 0.0 & $11.2( \pm 21.9)$ \\
\hline Salvinia auriculata & $21.3( \pm 30.9)$ & $7.3( \pm 11.2)$ & $8.6( \pm 25.7)$ & $0.1( \pm 0.3)$ & 0.0 & $0.7( \pm 0.6)$ \\
\hline Nymphoides indica & $0.3( \pm 1.2)$ & $1.3( \pm 3.1)$ & $5.8( \pm 14.2)$ & $2.3( \pm 2.0)$ & $37.6( \pm 43.1)$ & $4.3( \pm 8.5)$ \\
\hline Egeria densa & 0.0 & $0.1( \pm 0.3)$ & $0.7( \pm 1.2)$ & $1.0( \pm 1.1)$ & 0.0 & 0.0 \\
\hline Tonina sp. & $1.5( \pm 3.9)$ & $2.8( \pm 5.5)$ & $0.2( \pm 0.6)$ & 0.0 & 0.0 & 0.0 \\
\hline Montrichardia arborescens & 0.0 & 0.0 & $0.3( \pm 0.9)$ & 0.0 & 0.0 & 0.0 \\
\hline Pistia stratiotes & 0.0 & 0.0 & 0.0 & 0.0 & 0.0 & $0.1( \pm 0.3)$ \\
\hline Eleocharis sp. & $5.8( \pm 11.8)$ & $8.8( \pm 16.2)$ & $14.6( \pm 33.0)$ & $7.5( \pm 17.5)$ & $15.7( \pm 27.5)$ & $26.7( \pm 39.4)$ \\
\hline \multicolumn{7}{|l|}{ Habitat structures } \\
\hline Grass & $7.7( \pm 12.2)$ & $5.6( \pm 6.8)$ & $13.8( \pm 20.1)$ & $72.1( \pm 17.5)$ & $31.1( \pm 30.7)$ & $20.9( \pm 21.6)$ \\
\hline Submerged vegetation & $3.1( \pm 2.9)$ & $2.9( \pm 3.3)$ & $3.3( \pm 3.6)$ & $3.1( \pm 4.9)$ & $13.3( \pm 21.3)$ & $2.8( \pm 3.3)$ \\
\hline Vegetal cover & $78.7( \pm 12.2)$ & $81.8( \pm 10.7)$ & $67.3( \pm 26.6)$ & 0.0 & $2.9( \pm 6.9)$ & 0.0 \\
\hline Leaf litter & $82.6( \pm 16.9)$ & $29.3( \pm 20.2)$ & $44.2( \pm 31.2)$ & $40.0( \pm 19.7)$ & $17.6( \pm 13.9)$ & $55.2( \pm 27.6)$ \\
\hline Filamentous algae & $0.2( \pm 0.4)$ & $0.2( \pm 0.6)$ & $0.8( \pm 1.5)$ & $0.4( \pm 0.5)$ & 0.0 & 0.0 \\
\hline Attached algae & 0.0 & 0.0 & 0.0 & 0.0 & 0.0 & 0.0 \\
\hline Root masses & $4.2( \pm 11.4)$ & $3.6( \pm 8.0)$ & $0.8( \pm 2.9)$ & 0.0 & 0.0 & 0.0 \\
\hline Large debris & $10.1( \pm 11.5)$ & $11.8( \pm 15.6)$ & $7.2( \pm 11.7)$ & $0.3( \pm 0.9)$ & $0.3( \pm 0.9)$ & $1.7( \pm 5.6)$ \\
\hline Small debris & $3.9( \pm 3.8)$ & $0.4( \pm 0.7)$ & $0.8( \pm 1.6)$ & $0.6( \pm 1.5)$ & $0.7( \pm 1.6)$ & $0.4( \pm 0.7)$ \\
\hline Maximum depth & $131.7( \pm 6.4)$ & $143.8( \pm 0.3)$ & $130.7( \pm 23.5)$ & $138.3( \pm 5.5)$ & $144.0( \pm 1.7)$ & $140.7( \pm 1.2)$ \\
\hline Habitat depth & $42.6( \pm 21.0)$ & $33.1( \pm 8.3)$ & $39.2( \pm 14.1)$ & $27.6( \pm 15.5)$ & $25.2( \pm 14.1)$ & $16.1( \pm 1.7)$ \\
\hline \multicolumn{7}{|l|}{ Substrate composition } \\
\hline Mud & $35.8( \pm 36.7)$ & $78.8( \pm 28.1)$ & $65.3( \pm 36.4)$ & $6.0( \pm 5.2)$ & $12.0( \pm 7.3)$ & $3.0( \pm 2.0)$ \\
\hline Sand & $63.8( \pm 36.5)$ & $16.7( \pm 18.6)$ & $34.6( \pm 36.2)$ & $80.3( \pm 20.6)$ & $86.2( \pm 6.6)$ & $94.6( \pm 1.3)$ \\
\hline Small gravel & $0.3( \pm 0.9)$ & $4.6( \pm 13.0)$ & $0.2( \pm 0.6)$ & $13.8( \pm 22.4)$ & $1.8( \pm 2.3)$ & $2.4( \pm 0.9)$ \\
\hline Large gravel & 0.0 & 0.0 & 0.0 & 0.0 & $0.1( \pm 0.3)$ & 0.0 \\
\hline Cobbles & 0.0 & 0.0 & 0.0 & 0.0 & 0.0 & 0.0 \\
\hline Rocks & 0.0 & 0.0 & 0.0 & 0.0 & 0.0 & 0.0 \\
\hline Bedrock & 0.0 & 0.0 & 0.0 & 0.0 & 0.0 & 0.0 \\
\hline
\end{tabular}




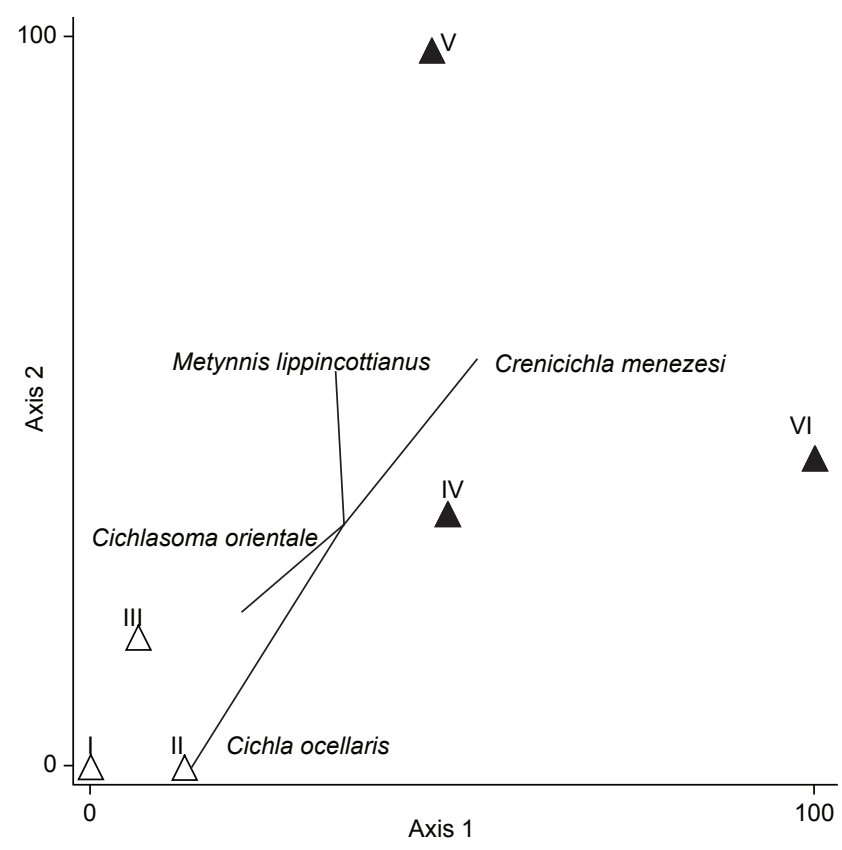

Figure 3. Biplot of NMS two-dimensional solution (Stress $=3.7$ ) based on habitat elements of the study sites and fish species correlated $\left(r^{2}>0.2\right)$ with sampling sites in ordination space (denoted by vectors). The direction and length of vectors indicate strength of correlation. Sites are coded as $\boldsymbol{\Delta}=$ non-forested sites and $\Delta=$ forested sites

Figura 3. Sobreposição da solução bi-dimensional da ordenação (stress = 3.7) baseada na estrutura do habitat e das espécies de peixes correlacionadas $\left(r^{2}>0.2\right)$ com os pontos de coleta (mostrada pelos vetores). A direção e comprimento dos vetores indica a força da correlação. Os pontos de coleta estão codificados como $\boldsymbol{\Delta}$ = pontos onde a mata ciliar está presente e $\Delta=$ pontos onde a mata ciliar está ausente. over the center and top right of the ordination plot. Sites I, II and III (where there is still riparian vegetation remaining) are negatively correlated with axes 1 and 2, therefore being arrayed to the bottom left of the ordination plot. The average distance (which represents how much far apart a group of points is compared to other group in the same ordination) was greater among sites were the riparian vegetation was removed (average distance between sites $=0.45$ ) than among sites with remaining vegetal cover (average distance between sites $=0.21$ ), thus the greater spread of sites IV, V and VI in the ordination plot. Furthermore, the Multi-Response Permutation Procedure reveals that the variation in habitat structure between both areas is significant $(\mathrm{A}=0.33, \mathrm{p}<0.05)$. Interestingly, the physico-chemical parameters and nutrients measured remained fairly constant across all sites (Table 3).

The overall richness and abundance of fish in the study sites was low (Table 4). However, the biplot of habitat elements ordination and abundance of fish (Figure 3) indicates that Metynnis lippincottianus and Crenicichla menezesi were more associated with the habitat in areas where natural riparian vegetation was absent. These species had higher positive correlation with axis 2 (Pearson correlations $=0.653$ and 0.683 , respectively) (Table 4), which describes non-forested sites. On the other hand Cichlasoma orientale and Cichla ocellaris were negatively correlated with both axes (1 and 2), which describe the forested sites. More importantly, Cichla ocellaris was highly negatively correlated with axis 2 , indicating strong dependence on forested areas (Table 4).

\section{Discussion}

The present study shows that the structure of the marginal habitat was different between areas where the riparian cover has been removed and replaced by sugar cane and areas where the natural vegetation cover was left unchanged. Both richness and composition of habitat elements were different between these two areas. The im-

Table 3. Average values ( \pm standard deviation) of water quality parameters for the study sites in the Gramame reservoir, Paraíba, Brazil. n.d. $=$ not detected. *represents the only detected value of the three sub-samples analyzed.

Tabela 3. Valores médios ( \pm desvio padrão) dos parâmetros de qualidade da água para os pontos de coleta (reservatório de Gramame, Paraíba, Brasil). n.d. = não detectado pelo método. *representa o único valor detectado pelo método das três sub-amostras analisadas.

\begin{tabular}{|c|c|c|c|c|c|c|}
\hline Area & \multicolumn{3}{|c|}{ Forested margins } & \multicolumn{3}{|c|}{ Non-forested margins } \\
\hline Sampling sites & $\mathbf{I}$ & II & III & IV & $\mathbf{V}$ & VI \\
\hline \multirow[t]{2}{*}{ Ammonium $(\mu \mathrm{g} / \mathrm{L})$} & 117.3 & 136.5 & 76.6 & 145.9 & 98.2 & 125.8 \\
\hline & $( \pm 54.0)$ & $( \pm 72.8)$ & $( \pm 30.0)$ & $( \pm 35.9)$ & $( \pm 3.3)$ & $( \pm 49.8)$ \\
\hline \multirow[t]{2}{*}{ Nitrite $(\mu \mathrm{g} / \mathrm{L})$} & 5.5 & 3.5 & 2.9 & 3.1 & 3.3 & 5.2 \\
\hline & $( \pm 0.9)$ & $( \pm 1.2)$ & $( \pm 1.5)$ & $( \pm 0.5)$ & $( \pm 0.9)$ & $( \pm 1.0)$ \\
\hline Total phosphorus $(\mu \mathrm{g} / \mathrm{L})$ & $0.4^{*}$ & n.d. & n.d. & n.d. & n.d. & n.d. \\
\hline Chlorophyll-a $(\mu \mathrm{g} / \mathrm{L})$ & 4.4 & 10.9 & 6.6 & 5.5 & 8.7 & 8.2 \\
\hline \multirow[t]{2}{*}{$\mathrm{pH}$} & 8.0 & 8.2 & 8.0 & 8.0 & 8.0 & 8.6 \\
\hline & $( \pm 0.1)$ & $( \pm 0.1)$ & $( \pm 0.2)$ & $( \pm 0.1)$ & $( \pm 0.2)$ & $( \pm 0.2)$ \\
\hline Conductivity $(\mu \mathrm{S} / \mathrm{cm})$ & n.d. & n.d. & n.d. & n.d. & n.d. & n.d. \\
\hline \multirow[t]{2}{*}{ Transparency $(\mathrm{cm})$} & 148.3 & 131.0 & 121.0 & 126.7 & 136.7 & 128.7 \\
\hline & $( \pm 9.9)$ & $( \pm 3.0)$ & $( \pm 3.6)$ & $( \pm 8.5)$ & $( \pm 1.5)$ & $( \pm 12.7)$ \\
\hline \multirow[t]{2}{*}{ Dissolved Oxygen (mg/L) } & 7.4 & 7.1 & 7.0 & 7.6 & 7.3 & 7.8 \\
\hline & $( \pm 0.1)$ & $( \pm 0.2)$ & $( \pm 0.3)$ & $( \pm 0.2)$ & $( \pm 0.0)$ & $( \pm 0.2)$ \\
\hline \multirow[t]{2}{*}{ Temperature $\left({ }^{\circ} \mathrm{C}\right)$} & 29.0 & 27.7 & 27.7 & 28.6 & 27.7 & 27.8 \\
\hline & $( \pm 0.1)$ & $( \pm 0.8)$ & $( \pm 0.8)$ & $( \pm 0.4)$ & $( \pm 0.0)$ & $( \pm 0.2)$ \\
\hline
\end{tabular}


Table 4. Number of fish collected in the study sites (Gramame reservoir, Paraíba, Brazil) and correlations between each species and the ordination axes from Figure 3.

Tabela 4. Abundância de peixes coletados nos pontos de coleta (reservatório de Gramame, Paraíba, Brasil) e correlações entre cada espécie e os eixos da ordenação na Figura 3.

\begin{tabular}{lcccccccc}
\hline \multicolumn{1}{c}{ Area } & Forested & \multicolumn{2}{c}{ Non-forested } & \multicolumn{3}{c}{ Pearson correlations } \\
\hline \multicolumn{1}{c}{ Sampling sites } & I & II & III & IV & V & VI & Axis 1 & Axis 2 \\
\hline Cichla ocellaris & 7 & 11 & 7 & 8 & 1 & 2 & -0.651 & -0.821 \\
Metynnis lippincottianus & 1 & 5 & 10 & 8 & 14 & 1 & -0.125 & 0.653 \\
Crenicichla menezesi & 0 & 0 & 1 & 1 & 1 & 1 & 0.605 & 0.683 \\
Cichlasoma orientale & 0 & 1 & 1 & 0 & 0 & 0 & -0.539 & -0.487 \\
\hline
\end{tabular}

portance of the riparian zone and its interface with the aquatic habitat is well recognized (Gregory et al. 1991, Medeiros et al. 2008). These structurally complex habitat types provide a growth substrate, source of food and spawning sites, as well as protection from predators for aquatic invertebrates and fish (Pusey \& Arthington 2003). Studies show that the greater diversity of microhabitats associated with the riparian vegetation leads to a greater diversity of species in forested areas (Gregory et al. 1991). In the present study, the marginal habitat with natural riparian vegetation showed a greater array of habitat elements, such as macrophytes and underwater structures.

The overall lower littoral depths in the study sites where the natural riparian cover was removed is in accordance with other studies (Holanda et al. 2005) which indicate that the removal of the riparian vegetal cover may lead to bank destabilization and increased erosion and sedimentation in the aquatic habitat. In the present study, a high proportion of sand and small gravel in the aquatic substrate composition in areas where the riparian cover was removed are an indication that the exposure of the soil and the consequent erosion are adding coarse sediments to the substrate. This may also be aggravated by the low amount of aquatic macrophytes, which provide particulate organic matter by decomposition.

Studies indicate that the water quality is closely associated with the riparian vegetal cover (Howard-Williams \& Pickmere 1994, Teti 2000, Søvik \& Syversen 2008). Temperatures for instance tend to increase in marginal habitats after removal of the riparian cover due to the decrease in shading, and such changes usually affect other physico-chemical factors such as conductivity and $\mathrm{pH}$ (Teti 2000). Also, dissolved nutrient concentrations tend to change with the removal of the riparian vegetation, since this vegetation absorbs nutrients rapidly and also provides nutrients through decomposition of vegetal parts fallen into the water (Howard-Williams \& Pickmere 1994, Søvik \& Syversen 2008). Pesticides and fertilizers associated with agricultural practices in areas where riparian vegetation has been removed are also associated with changes in nutrient concentration (Howard-Williams \& Pickmere 1994). In the present study, both nutrient concentration and physico-chemical parameters did not show expressive difference between areas with and without riparian vegetation. All nutrients (nitrite, total phosphorus, conductivity, chlorophyll- $\alpha$ and ammonium) and physico-chemical parameters $(\mathrm{pH}$, dissolved oxygen, temperature and transparency) presented similar values across the study sites. It is important to bear in mind that most of the studies cited above were performed in stream habitats where the volume of water is smaller than in a large reservoir like the one studied. Therefore, the currents and surface movements of water, characteristic of such a large water body, which are created by wind and inflow of small tributaries may be important factors in homogenizing the measured water quality parameters among the study sites.

The present study reveals a depauperate fish fauna in the Gramame reservoir, when compared to the fauna before the impoundment (Torelli et al. 1997, Gomes-Filho \& Rosa 2001), with only four species recorded and two of them introduced (non-native). Even though reservoirs are generally less diverse in fish species than rivers and streams (Medeiros et al. 2006), the diversity found in the present study is very low. The aquatic fauna has traditionally been associated to habitat heterogeneity (Medeiros et al. 2008). Therefore, the fact that the Gramame reservoir has been suffering from a significant loss of the marginal habitat elements due to the removal of the riparian vegetation may be affecting the fish fauna. Either directly due to loss of habitat and spawning sites or indirectly due to loss of feeding resources such as aquatic invertebrates, which are highly dependent on the marginal habitat for shelter and food (Sheldon et al. 2002). Furthermore, the introduction of exotic species such as the piscivorous Cichla ocellaris and the highly prolific Metynnis lippincottianus may have led to the loss of native species due to competition and predation, as mentioned for other reservoirs (Gurgel \& Oliveira 1987, Godinho et al. 1994, Canan \& Gurgel 1997).

Several studies emphasize the close correlation between fish species and the marginal habitat (Vono \& Barbosa 2001, Pusey \& Arthington 2003). Results provided by the present study are not conclusive about the relationship between fish species diversity and presence or absence of riparian vegetation, given that all four species were recorded in forested margins whereas three species were recorded in non-forested margins. Nevertheless, analysis of ordination showed a clear tendency of some species to be more associated to forested margins (namely Cichlasoma orientale and Cichla ocellaris) and others to be associated to non-forested sites (Metynnis lippincottianus and Crenicichla menezesi). In addition to that, Cichlasoma orientale was the only species that occurred exclusively on forested margins of the study sites.

In the Gramame reservoir, there is a strong need to restore the riparian vegetation with species that have a fast vegetative growth in order to minimize the effects of bank erosion and to provide habitat for the aquatic fauna. In areas with sugar cane or other types of plantation, it is suggested that the natural vegetal cover near the terrestrial-aquatic interface has to be maintained and/or restored in order to ensure the preservation of vital processes that lead to the production of plant seeds, habitats for pollinators and increase dispersal agents and, as a consequence, contribute to the aquatic production and biodiversity. Even though native species are the best choice for the riparian cover, species that yield fruits, flowers for honey production and medicines may also be an option, which could stimulate the involvement of landholders and/or other riverine communities in the processes of restoration, and consequently recover the biodiversity. 


\section{Acknowledgements}

The authors are grateful to M.Sc. Telton P. A. Ramos, from Programa de Pos-Graduação em Ciências Biológicas of Universidade Federal da Paraíba, for assistance with the identification of fish species. Elvio Medeiros is grateful to $\mathrm{CNPq} / \mathrm{UEPB} / \mathrm{DCR}$ for financial support (350082/2006-5). Fishing was performed under IBAMA License no. 10649-1 from 24 May 2007.

\section{References}

American Public Health Association - APHA. 1998. Standard methods for the examination of water and wastewater. APHA, Washington.

BAILEY, J., GATHERCOLE, P., HOUSBY, T. \& MOSS, D. 2001. The new encyclopedia of fishing: the complete guide to the fish, tackle and techniques of fresh and saltwater angling. Dorling Kindersley, London.

BIONDINI, M.E., BONHAM, C.D. \& REDENTE, E.F. 1985. Secondary successional patterns in a sagebrush (Artemisia tridentata) community as they relate to soil disturbance and soil biological activity. Vegetatio. 60(1):25-36

BOYS, C.A. \& THOMS, M.C. 2006. A large-scale, hierarchical approach for assessing habitat associations of fish assemblages in large dryland rivers. Hydrobiologia. 572(1):11-31.

BUNN, S.E., DAVIES, P.M. \& MOSISCH, T.D. 1999. Ecosystem measures of river health and their response to riparian and catchment degradation. Freshwat. Biol. 41(2):333-345.

CANAN, B. \& GURGEL, H.D.C.B. 1997. Estrutura populacional de Metynnis roosevelti Eigenmann, 1915 (Characidae, Myleinae) da lagoa do Jiqui, Parnamirim, Rio Grande do Norte. Rev. UNIMAR. 19(2):479-491.

GODINHO, A.L., FONSECA, M.T.D. \& ARAÚJO, L.M.D. 1994. The ecology of predator fish introductions: the case of rio Doce Valley lakes. In Ecology and human impact on lakes and reservoirs in Minas Gerais with special reference to future development and management strategies (R.M. Pinto-Coelho, A. Giani \& E. Von Sperling, eds.). SEGRAC, Belo Horizonte, p. 77-83.

GOLDFARB, M.C., CYSNEIROS, D.O. \& SILVA, T.C. 2002. Caracterização fluvio-morfológica da bacia do rio Gramame. In Bacia do Rio Gramame: hidrologia e aspectos ambientais para gestão dos seus recursos hídricos (T.C. Silva, A.M.B.P. Silans \& C.L. Gadelha, eds.). Editora Universitária, João Pessoa, p. 3-12

GOMES-FILHO, G. \& ROSA, R.S. 2001. Inventário da ictiofauna da bacia do rio Gramame, Paraíba, Brasil. In A bacia do Rio Gramame: biodiversidade, uso e conservação (T. Watanabe, ed.). PRODEMA, João Pessoa, p. 167-173.

GREGORY, S.V., SWANSON, F.J., MCKEE, W.A. \& CUMMINS, K.W. 1991. An ecosystem perspective of riparian zones. BioScience. 41(8):540-551.

GURGEL, J.J.S. \& OLIVEIRA, A.G. 1987. Efeitos da introdução de peixes e crustáceos no semi-árido do Nordeste brasileiro. Coleção Mossoroense, Série B. 453: 7-32.

HOLANDA, F.S.R., SANTOS, L.G.D.C., SANTOS, C.M.D., CASADO, A.P.B., PEDROTTI, A. \& RIBEIRO, G.T. 2005. Riparian vegetation affected by bank erosion in the lower São Francisco River, Northeastern Brazil. Rev. Árvore. 29(2):327-336.

HOWARD-WILLIAMS, C. \& PICKMERE, S. 1994. Long-term vegetation and water quality changes associated with the restoration of a pasture stream. In Restoration of aquatic habitats: selected papers from the second day of the New Zealand Limnological Society 1993 Annual Conference (K.J. Collier, ed.). Department of Conservation, Wellington, p. 93-109.

JUNK, W.J., BAYLEY, P.B. \& SPARKS, R.E. 1989. The flood pulse concept in river-floodplain systems. In Proceedings of the International Large Rivers Symposium (D.P. Dodge, ed.). Can. Spec. Publ. Fish. Aquat. Sci. 106. Ottawa, p. 110-127.

LORENZEN, C. 1967. Determination of chlorophyll and pheo-pigments: spectrophotometric equations. Limnol. Oceanogr. 12(2):343-346.

MAGURRAN, A.E. 1996. Ecological diversity and its measurement. Chapman \& Hall, London.
MCCUNE, B. \& GRACE, J.B. 2002. Analysis of ecological communities. MjM Software Design, Gleneden Beach.

MCCUNE, B. \& MEFFORD, M.J. 1999. PC-ORD: multivariate analysis of ecological data. Version 4.27 edition. MjM Software Design, Gleneden Beach.

MEDEIROS, E.S.F., RAMOS, R.T.C., RAMOS, T.P.A. \& SILVA, M.J. 2006. Spatial variation in reservoir fish assemblages along a semi-arid intermittent river, Curimataú River, northeastern Brazil. Rev. Biol. Ciênc. Terra. Supl. Esp. (1):29-39.

MEDEIROS, E.S.F., SILVA, M.J. \& RAMOS, R.T.C. 2008. Application of catchment- and local-scale variables for aquatic habitat characterization and assessment in the Brazilian semi-arid region. Neotr. Biol. Conserv. 3(1):13-20

MUGODO, J., KENNARD, M.J., LISTON, P., NICHOLS, S., LINKE, S., NORRIS, R.H. \& LINTERMANS, M. 2006. Local stream habitat variables predicted from catchment scale characteristics are useful for predicting fish distribution. Hydrobiologia. 572(1):59-70.

PUSEY, B.J. \& ARTHINGTON, A.H. 2003. Importance of the riparian zone to the conservation and management of freshwater fish: a review. Mar. Freshwater Res. 54(1):1-16.

RICHARDS, C., HARO, R.J., JOHNSON, B.L. \& HOST, G.E. 1997. Catchment and reach-scale properties as indicators of macroinvertebrate species traits. Freshwat. Biol. 37(1):219-230.

SANTOS, J.B., FILHO, L.A.P., SILANS, A.M.B.P. \& SILVA, T.C. 2002 Análise de áreas para preservação e conservação dos cursos d'água da bacia do rio Gramame. In Bacia do Rio Gramame: hidrologia e aspectos ambientais para gestão dos seus recursos hídricos (T.C. Silva, A.M.B.P. Silans \& C.L. Gadelha, eds.). Editora Universitária, João Pessoa, p. 43-52.

SHELDON, F., BOULTON, A.J. \& PUCKRIDGE, J.T. 2002. Conservation value of variable connectivity: aquatic invertebrate assemblages of channel and floodplain abitats of a central Australian arid-zone river, Cooper Creek. Biol Conserv. 103(1):13-31.

SILVA, T.C., SILANS, A.M.B.P., FILHO, L.A.P., PAIVA, A.E.D.B., BILLIB, M. \& BOOCHS, P. 2002a. Planejamento dos recursos hídricos na bacia hidrográfica do rio Gramame, uma bacia litorânea do Nordeste brasileiro. In Bacia do Rio Gramame: idrologia e aspectos ambientais para gestão dos seus recursos hídricos (T.C. Silva, A.M.B.P. Silans \& C.L. Gadelha, eds.). Editora Universitária, João Pessoa, p. 55-178.

SILVA, T.C., SILANS, A.M.B.P. \& GADELHA, C.L. 2002b. Bacia do Rio Gramame: hidrologia e aspectos ambientais para gestão dos seus recursos hídricos. Editora Universitária, João Pessoa.

SØVIK, A.K. \& SYVERSEN, N. 2008. Retention of particles and nutrients in the root zone of a vegetative buffer zone: effect of vegetation and season. Boreal Environ. Res. 13(3):223-230.

Superintendência de Administração do Meio Ambiente - SUDEMA. 2004. Atualização do diagnóstico florestal do Estado da Paraíba. SUDEMA, João Pessoa.

TETI, P. 2000. Riparian management and stream temperature. In Proceedings of from science to management and back: a science forum for southern interior ecosystems of British Columbia (C. Hollstedt, K. Sutherland \& T. Innes, eds.). Southern Interior Forest Extension and Research Partnership, Kamloops, p. 27-28.

TORELLI, J., ROSA, I.L. \& WATANABE, T. 1997. Ictiofauna do rio Gramame, Paraíba, Brasil. Iheringia, Sér. Zool. 82(1):67-73.

VANNOTE, R.L., MinSHALL, G.W., CUMMINS, K.W., SEDELL, J.R. \& CUSHING, C.E. 1980. The river continuum concept. Can. J. Fish. Aquat. Sci. 37(1):130-137.

VONO, V. \& BARBOSA, F.A.R. 2001. Habitats and littoral zone fish community structure of two natural lakes in southeast Brazil. Environ. Biol. Fish. 61(4):371-379. 